\title{
Leaf Rust Resistance and Molecular Identification of Lr 34 Gene in Egyptian Wheat
}

\author{
Fahmi Al $^{1 *}$, El-Shehawi $\mathrm{AM}^{2,3}$ and El-Orabey WM ${ }^{4}$
}

${ }^{1}$ Department of Genetics, Faculty of Agriculture, Menoufiya University, Shibin El-Kom, Egypt ${ }^{2}$ Department of Biotechnology, Faculty of Science, Taif University, Taif, Saudi Arabia

${ }^{3}$ Department of Genetics, Faculty of Agriculture, University of Alexandria, Alexandria, Egypt

${ }^{4}$ Wheat Diseases Res. Department, Plant Pathology Res. Institute, ARC, Giza, Egypt

\begin{abstract}
Twenty six wheat genotypes were evaluated for their levels of adult plant resistance to leaf rust at two different locations i.e. Shibin El-Kom and Itay El-Baroud during two successive growing seasons, i.e., 2011/12 and 2012/13. The wheat varieties Sids 12, Sids 13, Misr 1 and Misr 2, Shandweel 1, Beni Sweif 4 and Beni Sweif 5 have race-specific resistance. While, the wheat genotypes $\operatorname{Lr} 34$, Giza 165, Giza 168, Sakha 8, Sakha 94, Sakha 95, Gemmeiza 5, Gemmeiza 7, Gemmeiza 9, Gemmeiza 10, Gemmeiza 11 and Sohag 3 showed high levels of slow rusting resistance. On the other hand, the other tested varieties were highly susceptible or fast rusting ones i.e. Giza 160, Giza 163, Giza 164, Sakha 69, Sakha 93, Sids 1 and Giza 139. These varieties showed higher values of final rust severity (\%) and AUDPC compared to the other varieties under the same field conditions. SSR marker i.e. cslv34b allele (150 bp) for $L r 34$ was used to confirm the presence of the adult plant resistance gene $L r 34$ in the tested genotypes.
\end{abstract}

Keywords: Wheat; Puccinia triticina; AUDPC; Partial resistance; Molecular markers

\section{Introduction}

Within the last twenty years, wheat has become the most important crop in Egypt. Egypt seeks to increase productivity and yields in order to meet the target of producing $75 \%$ of its own wheat needs [1]. Leaf rust or brown rust caused by Puccinia triticina (formerly known as Puccinia recondita $\mathrm{f}$. $\mathrm{sp}$. tritici) has been the most frequent disease in wheat producing areas [2]. Studies in Egypt estimated crop losses of up to $50 \%$ due to leaf rust infection [3].

The cultivation of resistant varieties remains the most economic and environmentally preferable method to manage this disease. To date, 80 genes and alleles of leaf rust resistance genes in wheat have been mapped to chromosome location and given gene designations [4]. Some of the resistance genes are effective at seedling stage and they are race specific [5]. Several of these genes may become ineffective due to the emergence of new virulent races and also because of rapid evolution and adaptation of pathogen [6]. In contrast, others are effective through the adult plant stage and are referred to as slow rusting genes and they are race non-specific provide durable resistance or a broad spectrum of races. Therefore, a cultivar that only has slow rusting resistance to leaf rust will display susceptible infection type response throughout the entire lifecycle of the plant [7]. Slow rusting resistance can be measured in the field by recording disease severity at weekly intervals and then calculating the area under disease progress curve (AUDPC) [8].

One of these important race-nonspecific resistance genes is $\operatorname{Lr} 34$. It is located on the short arm of chromosome 7D and it encodes ATP binding cassette $(\mathrm{ABC})$ transporter [9]. Also, it is associated with leaf tip necrosis, adult plant resistance to stem rust, adult plant resistance gene $\mathrm{Yr} 18$ to stripe rust, and tolerance to barley yellow dwarf virus [10].

Efficient incorporation of $\operatorname{Lr} 34$ in adapted germplasm using traditional methods was difficult because of its quantitative inheritance nature. Thus, using of molecular marker technique is the best alternative methodology to identify and consequently to incorporate this important gene in economically important genotypes. Available information about $\operatorname{Lr} 34$ gene sequence provided good tool to develop and to track its introgression in different genotypes and consequently its pyramiding in commercial varieties [9]. Therefore, development of molecular marker for $\operatorname{Lr} 34 / 7 \mathrm{DS}$ region has been a major objective for marker assist selection (MAS) for this important gene. [11] were able to utilize the available knowledge about this locus to develop a specific codominant marker namely; csLV34. This marker had the ability to diagnose the $\operatorname{Lr} 34$ gene in diverse cultivar backgrounds [12]. It revealed a bi-allelic nature where $79 \mathrm{bp}$ deletions in an intron sequence were accompanied by the presence of $\operatorname{Lr} 34$ gene resistance. Several other markers that differentiate among the alleles of $\operatorname{Lr} 34$ have been described $[9,13]$.

Because of the superiority of molecular markers in MAS for genes in different genetic background even in highly bred cultivar under any environmental conditions, different types of molecular markers based on genetic variations have been developed in Egyptian wheat cultivars [14-17]. Also, haplotype polymorphism among Egyptian wheat varieties for $\operatorname{Lr}$ 34/7DS region had been studied using microsatellite markers [16]. Therefore, the objectives of the present investigations were: (1) to evaluate Egyptian wheat varieties to leaf rust at adult plant stage under field conditions and to identify the presence of $L r 34$ gene with $c s L V 34$ specific marker in Egyptian wheat varieties.

*Corresponding authors: Fahmi Al, Department of Genetics, Faculty of Agriculture, Menoufiya University, Shibin El-Kom, Egypt; 2Department of Biotechnology, Faculty of Science, Taif University, Taif, Saudi Arabia, Tel: 2048 222 170; Fax: 0020225769495; E-mail: abdelmegidfahmi@yahoo.com

Received September 19, 2015; Accepted October 17, 2015; Published October 24, 2015

Citation: Fahmi Al, El-Shehawi AM, El-Orabey WM (2015) Leaf Rust Resistance and Molecular Identification of $L r 34$ Gene in Egyptian Wheat. J Microb Biochem Technol 7: 338-343. doi:10.4172/1948-5948.1000236

Copyright: ( $) 2015$ Fahmi Al, et al. This is an open-access article distributed unde the terms of the Creative Commons Attribution License, which permits unrestricted use, distribution, and reproduction in any medium, provided the original author and source are credited. 
Citation: Fahmi Al, El-Shehawi AM, El-Orabey WM (2015) Leaf Rust Resistance and Molecular Identification of Lr 34 Gene in Egyptian Wheat. J Microb Biochem Technol 7: 338-343. doi:10.4172/1948-5948.1000236

\section{Materials and Methods}

\section{Plant materials}

Wheat varieties (Table 1) and $L r 34$ line were evaluated under field conditions at two locations namely; farm of the Faculty of Agriculture, Menoufiya University, Shibin El-Kom and Itay El-Baroud Agricultural Research Station, Egypt, for two successive seasons (2011/12 and 2012/13).

\section{Field inoculation of wheat genotypes and disease assessment}

The tested wheat genotypes were sown in rows and were surrounded by spreader plants (Morocco and Thatcher) which were moisture by a fine spray with water and dusted with a mixture of leaf rust urediniospores and talcum powder at the ratio of. 1:20 (v/v). The inoculation of all plants was carried out at botting stage [18]. Adult plant response was scored as rust severity (\%) for each genotype after disease on set till the early dough stage according to the scale proposed by [19]. Rust severity of each genotype was recorded every seven days after the appearance of initial infection, using the modified Cobbs scale [20]. Final rust severity (FRS) was recorded as outlined by [21], as disease severity (\%) when the highly susceptible check variety was severely rusted and the disease rate reached the highest severity. Also, area under disease progress curve (AUDPC) was estimated to compare different responses of the tested genotypes using the following equation:

$\mathrm{AUDPC}=\mathrm{D}[1 / 2(\mathrm{Y} 1+\mathrm{Yk})+\mathrm{Y} 2+\mathrm{Y} 3+\ldots \ldots . . \mathrm{Y}(\mathrm{k}-1)]$ as described by [22], where;
$\mathrm{D}=$ days between reading, $\mathrm{Y} 1=$ First disease recording and $\mathrm{Yk}=$ Last disease recording

\section{DNA extraction and $P C R$ reaction}

Young leaves were collected from two-week old plants of all genotypes and were subjected to CTAB protocol for genomic DNA Extraction, which is based on method of [23]. DNA concentration was estimated and used as PCR template. DNA samples were visualized on 1-2\% agarose. Polymerase chain reaction (PCR) was conducted to detect specific $\operatorname{Lr} 34$ gene fragment using specific primer namely; LrcsLV34 as described in [11]. The sequence of the forward primer is $5^{\prime}$ GTTGGTTAAGACTGGTGATGG3 and the reverse primer is 5'TGCTTGCTATTGCTGAATAGT3`. Polymerase Chain Reaction (PCR) was undertaken in $50 \mu \mathrm{L}$ total volume containing $5 \mu \mathrm{L}$ of $10 \mathrm{X}$ PCR buffer, $4 \mu \mathrm{L}$ ( $25 \mathrm{mM} \mathrm{MgCl}$ ), $1 \mu \mathrm{L}$ (10 ng) of DNA, $1 \mu \mathrm{L}$ (100 ng, 125 picomole) of primer (forward and reverse), 1 unite of Taq DNA polymerase. PCR amplification conditions were initial denaturation at $95^{\circ} \mathrm{C}$ for $5 \mathrm{~min}$, denaturation at $95^{\circ} \mathrm{C}$ for $1 \mathrm{~min}$, annealing at $55^{\circ} \mathrm{C}$ for $30 \mathrm{~s}$ for $35 \mathrm{cycles}$, extension at $72^{\circ} \mathrm{C} 1 \mathrm{~min}$, and final extension at $72^{\circ} \mathrm{C}$ for $5 \mathrm{~min}$. The PCR products were analyzed by electrophoretic separation in a 1-2\% agarose gel. DNA marker of 100 bp DNA ladder marker was added on one side of the gel to determine the size of the DNA pattern. Gel was stained with ethidium bromide.

Microsoft Excel 2010 (Microsoft Corporation, USA) computer program was used to draw the standard curve and to estimate fragment size.

\begin{tabular}{|c|c|c|}
\hline Variety & Pedigree & Year of release \\
\hline \multicolumn{3}{|c|}{ Bread wheat varieties } \\
\hline Giza 139 (check) & HINDI90/KENYA256G. & 1947 \\
\hline Sakha 8 & Indus 66 x Norteno "S"-Pk 348 & 1979 \\
\hline Sakha 69 & Inia/RL 4220//7C/Yr "S" CM 15430-25-65-0S-0S & 1980 \\
\hline Giza 160 & CHENAB/GIZA155. & 1982 \\
\hline Giza 163 & F-61-70/Bon//Cno /7C CM33009-F-15M-4Y-2M-1M-1M-1Y-0M & 1988 \\
\hline Giza 164 & KVZ/Buha "s"//Kal/Bb CM33027-F-15M-500y-0M & 1988 \\
\hline Giza 165 & 0MCno/Mfd//Mon "S" CM43339-C-1Y-1M-2Y-1M-2Y-0B & 1991 \\
\hline Sids 1 & HD2172/PAVON"S"//1158.574"S". SD46-4SD-2SD-1SD-0SD. & 1996 \\
\hline Gemmeiza 5 & VEE"S"/SWM6525. GM4017-1GM-6GM-3GM-0GM. & 1998 \\
\hline Giza 168 & MIL/BUC//Seri CM93046-8M-0Y-0M-2Y-0B & 1999 \\
\hline Gemmeiza 7 & CMH74A.630/SX//SER182/3/AGENT. GM4611-2GM-3GM-1GM-0GM. & 1999 \\
\hline Gemmeiza 9 & ALD"S"/HUAC"S"//CMH74A.630/SX. GM4583-5GM-1GM-0GM. & 1999 \\
\hline Sakha 93 & Sakha 92/TR 810328 S 8871-1S-2S-1S-0S & 1999 \\
\hline Gemmeiza 10 & MAYA74"S"/ON//160-147/3/BB/GLL/4/CHAT"S"/5/CROW"S". GM5820-3GM-1GM-2GM-0GM. & 2004 \\
\hline Sakha 94 & OPATA/RAYON//KAUZ. CMBW90Y3280-0TOPM-3Y-010M-010M-010Y-10M-015Y-0Y-0AP-0S. & 2004 \\
\hline Sids 12 & BUC//7C/ALD/5/MAYA74/ON//1160-147/3/BB/GLL/4/CHAT"S"/6/MAYA/VUL-4SD-1SD-1SD-0SD. & 2007 \\
\hline Sids 13 & KAUZ "S"//TSI/SNB"S". ICW94-0375-4AP-2AP-030AP-0APS-3AP-0APS-050AP-0AP-0SD. & 2010 \\
\hline Misr 1 & OASIS/SKAUZ//4*BCN/3/2*PASTOR. CMSSOY01881T-050M-030Y-O3OM-030WGY-33M-0Y-0S. & 2010 \\
\hline Misr 2 & SKAUZ/BAV92. CMSS96M0361S-1M-010SY-010M-010SY-8M-0Y-0S. & 2011 \\
\hline Gemmeiza 11 & B0W"S"/KVZ"S"//7C/SERI82/3/GIZA168/SAKHA61. GM7892-2GM-1GM-2GM-1GM-0GM. & 2011 \\
\hline Shandaweel 1 & SITE//MO/4/NAC/TH.AC//3*PVN/3/MIRLO/BUC. CMSS93B00567S-72Y-010M-010Y-010M-0HTY-0SH & 2011 \\
\hline Sakha 95 & SKAUZ*2_SRMA-CMBW91MO2694P-0T0PY-7M-010Y -010M-010Y-5 & \\
\hline Variety & Pedigree & Year of release \\
\hline \multicolumn{3}{|c|}{ Durum wheat varieties } \\
\hline Sohag 3 & MEXI"S"/MGHA/51792//DURUM6. CD21831-25H-1SH-0SH. & 1991 \\
\hline Beni Swear 4 & AUSL/5/CANDO/4/BY*2/TACE//II27655/3/TME//ZB/W*2. ICD88-1120-ABL-0TR-1BR-0TR-6AP-OSD. & 2007 \\
\hline Beni Swear 5 & DIPPERZ/BUSHEN3. CDSS92B128-1M-0Y-0M-0Y-3B-0Y-0SD. & 2007 \\
\hline \multicolumn{3}{|l|}{ Monogenic line } \\
\hline Lr 34 & Thatcher ${ }^{6} \mathrm{x}$ Lageadinho & 1982 \\
\hline
\end{tabular}

Table 1: List of the local wheat varieties that were used, pedigree and year of release. 


\section{Results}

To assess leaf rust disease resistance of some Egyptian wheat varieties, final rust severity (FRS \%) and area under disease progress curve (AUDCP) were determined.

\section{Season 2011/12}

Data presented in Table 2 showed that, the tested genotypes could be classified into three main groups on the basis of FRS (\%) and AUDPC values. The first group included the wheat varieties with racespecific resistance which displayed the lowest values of FRS (\%) and AUDPC. This group included the wheat varieties Sids 12, Misr 1, Misr 2, Shandaweel 1, Beni Sweif 4 and Beni Sweif 5 which were immune and showed zero percent rust severity and Sids 13 ( $\operatorname{Tr}$ MR) at Shibin El-Kom location. Meanwhile, at Itay El-Baroud location the wheat varieties Shandaweel 1 and Beni Sweif 5 showed zero percent rust severity, Sids 12, Sids 13, Misr 1 and Beni Sweif 4 (each with $\operatorname{Tr} M R$ ) and Misr 2 (5 MR) showed the lowest values of FRS (\%). Moreover, these varieties showed the lowest values of AUDPC ranged from 0 to 49 at the two locations. The second group included the wheat genotypes which displayed low values of FRS (\%) and AUDPC (less than 300). Therefore, they were characterized as slow rusting varieties or partially resistant varieties. This group included the wheat genotypes $\operatorname{Lr} 34$

\begin{tabular}{|c|c|c|c|c|}
\hline \multirow[b]{2}{*}{ Genotype } & \multicolumn{2}{|c|}{ FRS (\%) } & \multicolumn{2}{|c|}{ AUDPC } \\
\hline & $\begin{array}{c}\text { Shebin El- } \\
\text { Kom }\end{array}$ & $\begin{array}{l}\text { Itay El- } \\
\text { Baroud }\end{array}$ & Shebin El-Kom & Itay El-Baroud \\
\hline \multicolumn{5}{|c|}{ Group I: Varieties with race specific resistance } \\
\hline Sids 12 & 0 & $\operatorname{Tr} M R$ & 0 & 42.0 \\
\hline Sids 13 & $\operatorname{Tr} M R$ & $\operatorname{Tr} M R$ & 42.0 & 42.0 \\
\hline Misr 1 & 0 & $\operatorname{Tr} M R$ & 0 & 42.0 \\
\hline Misr 2 & 0 & $5 \mathrm{MR}$ & 0 & 49.0 \\
\hline Shandaweel 1 & 0 & 0 & 0 & 0 \\
\hline Beni Sweif 4 & 0 & $\operatorname{Tr} M R$ & 0 & 42.0 \\
\hline Beni Sweif 5 & 0 & 0 & 0 & 0 \\
\hline \multicolumn{5}{|c|}{ Group 2: Varieties with slow rusting resistance } \\
\hline $\operatorname{Lr} 34$ & Tr MS & $5 \mathrm{MS}$ & 42.0 & 49.0 \\
\hline Giza 165 & $20 \mathrm{~S}$ & $30 \mathrm{~S}$ & 157.5 & 192.5 \\
\hline Giza 168 & $10 \mathrm{~S}$ & $10 \mathrm{~S}$ & 66.5 & 66.5 \\
\hline Sakha 8 & $5 \mathrm{~S}$ & $10 \mathrm{~S}$ & 49.0 & 66.5 \\
\hline Sakha 94 & $\operatorname{Tr} \mathrm{S}$ & $5 \mathrm{~S}$ & 42.0 & 49.0 \\
\hline Sakha 95 & $5 \mathrm{~S}$ & $10 \mathrm{~S}$ & 56.0 & 66.5 \\
\hline Gemmeiza 5 & $20 \mathrm{~S}$ & $30 \mathrm{~s}$ & 157.5 & 192.5 \\
\hline Gemmeiza 7 & $30 \mathrm{~s}$ & $20 \mathrm{~S}$ & 192.5 & 157.5 \\
\hline Gemmeiza 9 & $5 S$ & $10 \mathrm{~S}$ & 49.0 & 80.5 \\
\hline Gemmeiza 10 & $5 \mathrm{~S}$ & $5 \mathrm{~S}$ & 49.0 & 49.0 \\
\hline Gemmeiza 11 & $5 \mathrm{~S}$ & $10 \mathrm{~S}$ & 49.0 & 80.5 \\
\hline Sohag 3 & Tr MS & $5 S$ & 42.0 & 49.0 \\
\hline \multicolumn{5}{|c|}{ Group 3: Varieties with fast rusting resistance } \\
\hline Giza 160 & $30 \mathrm{~S}$ & $40 \mathrm{~S}$ & 315.0 & 315.0 \\
\hline Giza 163 & $30 \mathrm{~s}$ & $40 \mathrm{~S}$ & 385.0 & 420.0 \\
\hline Giza 164 & $30 \mathrm{~s}$ & $30 \mathrm{~s}$ & 315.0 & 315.0 \\
\hline Sakha 69 & $60 \mathrm{~s}$ & $30 \mathrm{~s}$ & 385.0 & 420.0 \\
\hline Sakha 93 & $50 \mathrm{~S}$ & $60 \mathrm{~s}$ & 560.0 & 560.0 \\
\hline Sids 1 & $70 \mathrm{~S}$ & $80 \mathrm{~S}$ & 560.0 & 630.0 \\
\hline $\begin{array}{c}\text { Giza } 139 \\
\text { (check) }\end{array}$ & $70 \mathrm{~S}$ & $90 \mathrm{~S}$ & 700.0 & 840.0 \\
\hline
\end{tabular}

Table 2: Percentage final leaf rust severity (FRS \%) and area under disease progress curve (AUDPC) of 26 wheat genotypes grown at Shebin El-Kom and Itay El-Baroud locations during 2011/12 growing season. and Sohag 3 (each with $\operatorname{Tr}$ MS), Sakha 94 (Tr S), Sakha 8, Sakha 95, Gemmeiza 9, Gemmeiza 10 and Gemmeiza 11 (each with 5 S), Giza 168 (10 S), Giza 165 and Gemmeiza 5 (each with 20 S) and Gemmeiza 7 $(30 \mathrm{~S})$ at Shibin El-Kom location. While, at Itay El-Baroud location $\mathrm{Lr}$ 34 (5 MS), Sakha 94 (5 S), Gemmeiza 10 (5 S), Sohag 3 (5 S), Giza 168 (10 S), Sakha 8 (10 S), Sakha 95 (10 S), Gemmeiza 9 (10 S), Gemmeiza 11 (10 S), Gemmeiza 7 (20 S), Giza 165 (30 S) and Gemmeiza 5 (30 S). Moreover, the wheat varieties in this group showed the lowest values of AUDPC at the two locations Shibin El-Kom and Itay El-Baroud ranged from 49 to 192.5. The third group included the wheat varieties which revealed the highest values of FRS (\%) and AUDPC than partially resistant ones (more than 300) and were identified as the fast rusters. This group included the wheat varieties Giza 160 (30 S), Giza 163 (30 S), Giza 164 (30 S), Sakha 93 (50 S), Sakha 69 (60 S), Giza 139 (60 S) and Sids 1 (70 S) at Shibin El-Kom location. While, at Itay El-Baroud location vars. Giza 164 (30 S), Sakha 69 (30 S), Giza 160 (40 S), Giza 163 (40 S), Sakha 93 (60 S), Sids 1 (80 S) and Giza 139 (90 S) showed the highest values of FRS (\%). Moreover, the wheat varieties Giza 160 (315), Giza 164 (315), Giza 163 (385), Sakha 69 (385), Sakha 93 (560), Sids 1 (560) and Giza 139 (700) showed high values of AUDPC at Shibin El-Kom location. While, at Itay El-Baroud these wheat varieties showed highest values of AUDPC i.e. 315, 315, 420, 420, 560, 630 and 840 , respectively.

\section{Season 2012/13}

Results given in Table 3 showed that the tested wheat varieties showed different levels of final rust severity (\%) ranging from 0 to $70 \mathrm{~S}$ at Shibin El-Kom location and from 0 to $80 \mathrm{~S}$ at Itay El-Baroud location. According to the response of the tested genotypes, they were divided into the same three groups of Table 2. 1. Race-specific resistant varieties: These varieties showed FRS (\%) from 0 to $5 \mathrm{MR}$ which included the wheat varieties Shandaweel 1, Beni Sweif 5, Sids 12, Sids 13, Misr 1, Misr 2 and Beni Sweif 4 at the two location Shibin El-Kom location and Itay El-Baroud. Meanwhile, these wheat varieties showed lowest values of AUDPC ranged from 0 to 49 at two locations. 2. Genotypes with slow rusting resistance which included the wheat genotypes Gemmeiza 11, $\operatorname{Lr}$ 34, Giza 168, Sakha 8, Sakha 94, Gemmeiza 9, Gemmeiza 10, Sohag 3, Giza 165, Sakha 95, Gemmeiza 7 and Gemmeiza 5 which showed low levels of FRS (\%) at Shibin El- Kom location i.e. Tr S, 5 MS, $5 \mathrm{~S}, 5 \mathrm{~S}, 5 \mathrm{~S}, 5 \mathrm{~S}, 5 \mathrm{~S}, 5 \mathrm{~S}, 10 \mathrm{~S}, 10 \mathrm{~S}, 20 \mathrm{~S}$ and $30 \mathrm{~S}$, respectively. While, at Itay El-Baroud location the wheat varieties Sakha 94 (5 S), Gemmeiza 9 (5 S), Gemmeiza 11 (5 S), Sohag 3 (5 S), Lr 34 (10 S), Giza 168 (10 S), Sakha 8 (10 S), Sakha 95 (10 S), Gemmeiza 10 (10 S), Giza 165 (20 S), Gemmeiza 5 (30 S) and Gemmeiza 7 (30 S) showed low values of FRS (\%). Moreover, the wheat varieties in this group showed low values of AUDPC at the two locations ranged from 49 to 192.5. 3. Fast rusting varieties including the wheat varieties Giza 160 (40 S), Giza 163 (40 S), Giza 164 (40 S), Sakha 69 (40 S), Sakha 93 (60 S), Sids 1 (60 S) and Giza 139 (70 S) which showed the highest values of FRS (\%) at Shibin El-Kom location. While, at Itay El-Baroud location the wheat varieties Giza 164 (30 S), Giza 163 (40 S), Sakha 69 (40 S), Giza 160 (50 S), Sakha 93 (60 S), Sids 1 (70 S) and Giza 139 (80 S) showed the highest values of FRS (\%). Moreover, the tested varieties in this group showed the highest values of AUDPC at the two locations ranged from 315 to 700 at Shibin El-Kom. While, at Itay El-Baroud the tested wheat varieties showed the highest values of AUDPC ranged from 315 to 840 .

\section{Molecular marker detection}

For further resistance evaluation of the wheat genotypes under investigation, the presence of the Lr 34 was investigated. The STS marker 
Citation: Fahmi Al, El-Shehawi AM, El-Orabey WM (2015) Leaf Rust Resistance and Molecular Identification of Lr 34 Gene in Egyptian Wheat. J Microb Biochem Technol 7: 338-343. doi:10.4172/1948-5948.1000236

for $\operatorname{Lr} 34$ gene was used to identify the presence of the resistance allele in genotypes under study. The $c s L V 34$ is a PCR-based marker and it was mapped $0.4 \mathrm{cM}$ from this gene and validated in many genotypes from different parts of the world [11]. In other words, this marker is capable of differentiating among lines with/out this gene. The csLV34 primer amplified two fragments of 150 and $229 \mathrm{bp}$ in positive and negative controls, respectively. The $c s L V 34$ a allele (229 bp) was detected in the check cultivar Giza 139 and $c s L V 34 \mathrm{~b}$ allele (150 bp) was detected in the near isogenic line Thatcher $\operatorname{Lr} 34$ (Figure 1). Five wheat varieties i.e. Sakha 8, Sakha 94, Sakha 95, Sids 13 and Shandweel 1 showed csLV34b allele. Based on the amplification of the $150 \mathrm{bp}$ fragment,

\begin{tabular}{|c|c|c|c|c|}
\hline \multirow[b]{2}{*}{ Genotype } & \multicolumn{2}{|c|}{ FRS (\%) } & \multicolumn{2}{|c|}{ AUDPC } \\
\hline & Shebin El-Kom & $\begin{array}{l}\text { Itay El- } \\
\text { Baroud }\end{array}$ & Shebin El-Kom & Itay El-Baroud \\
\hline \multicolumn{5}{|c|}{ Group I: Varieties with race specific resistance } \\
\hline Sids 12 & $\operatorname{Tr} \mathrm{MR}$ & $\operatorname{Tr}$ MR & 42.0 & 42.0 \\
\hline Sids 13 & $\operatorname{Tr} M R$ & $\operatorname{Tr} M R$ & 42.0 & 42.0 \\
\hline Misr 1 & $\operatorname{Tr} M R$ & $5 \mathrm{MR}$ & 42.0 & 49.0 \\
\hline Misr 2 & $\operatorname{Tr} \mathrm{MR}$ & $5 \mathrm{MR}$ & 42.0 & 49.0 \\
\hline Shandaweel 1 & 0 & 0 & 0 & 0 \\
\hline Beni Sweif 4 & $\operatorname{Tr} M R$ & $\operatorname{Tr} M R$ & 42.0 & 42.0 \\
\hline Beni Sweif 5 & 0 & 0 & 0 & 0 \\
\hline \multicolumn{5}{|c|}{ Group 2: Varieties with slow rusting resistance } \\
\hline $\operatorname{Lr} 34$ & $5 \mathrm{MS}$ & $10 \mathrm{~s}$ & 49.0 & 80.5 \\
\hline Giza 165 & $10 \mathrm{~S}$ & $20 \mathrm{~S}$ & 80.5 & 157.5 \\
\hline Giza 168 & $5 S$ & $10 \mathrm{~S}$ & 49.0 & 66.5 \\
\hline Sakha 8 & $5 \mathrm{~S}$ & $10 \mathrm{~S}$ & 49.0 & 66.5 \\
\hline Sakha 94 & $5 S$ & $5 S$ & 49.0 & 49.0 \\
\hline Sakha 95 & $10 \mathrm{~S}$ & $10 \mathrm{~S}$ & 66.5 & 66.5 \\
\hline Gemmeiza 5 & $30 \mathrm{~s}$ & $30 \mathrm{~s}$ & 192.5 & 192.5 \\
\hline Gemmeiza 7 & $20 \mathrm{~S}$ & $30 \mathrm{~s}$ & 157.5 & 192.5 \\
\hline Gemmeiza 9 & $5 \mathrm{~S}$ & $5 S$ & 49.0 & 49.0 \\
\hline Gemmeiza 10 & $5 \mathrm{~S}$ & $10 \mathrm{~S}$ & 49.0 & 66.5 \\
\hline Gemmeiza 11 & $\operatorname{TrS}$ & $5 \mathrm{~S}$ & 42.0 & 49.0 \\
\hline Sohag 3 & $5 S$ & $5 \mathrm{~S}$ & 49.0 & 49.0 \\
\hline \multicolumn{5}{|c|}{ Group 3: Varieties with fast rusting resistance } \\
\hline Giza 160 & $40 \mathrm{~S}$ & $50 \mathrm{~S}$ & 315.0 & 315.0 \\
\hline Giza 163 & $40 \mathrm{~S}$ & $40 \mathrm{~S}$ & 385.0 & 420.0 \\
\hline Giza 164 & $40 \mathrm{~S}$ & $30 \mathrm{~s}$ & 315.0 & 315.0 \\
\hline Sakha 69 & $40 \mathrm{~S}$ & $40 \mathrm{~S}$ & 385.0 & 420.0 \\
\hline Sakha 93 & $60 \mathrm{~S}$ & $60 \mathrm{~S}$ & 560.0 & 560.0 \\
\hline Sids 1 & $60 \mathrm{~S}$ & $70 \mathrm{~S}$ & 560.0 & 630.0 \\
\hline Giza 139 (check) & $70 \mathrm{~S}$ & $80 \mathrm{~S}$ & 700.0 & 840.0 \\
\hline
\end{tabular}

Table 3: Percentage final leaf rust severity (FRS \%) and area under disease progress curve (AUDPC) of 26 wheat genotypes grown at Shebin El-Kom and Itay El-Baroud locations during 2012/13 growing season.

$\begin{array}{llllllllllllllll}\text { a } & \text { bp } & \text { M } & 1 & 2 & 3 & 4 & 5 & 6 & 7 & 8 & 9 & 10 & 11 & 12 & 13\end{array}$

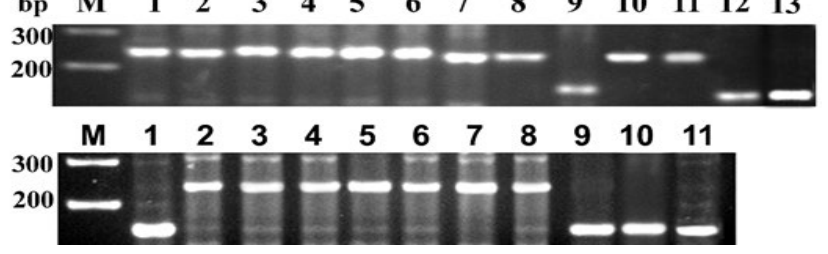

Figure 1: M: 100 bp ladder; a: 1: Misr 1, 2: Misr 2, 3: Giza 139, 4: Giza 160 5: Giza 163, 6: Giza 164, 7: Giza 165, 8: Giza 168, 9: Sakha 8, 10: Sakha 69, 10: Sakha 93, 12: Sakha 94, 13: $\operatorname{Lr} 34$; b: 1: Sakha 95, 2: Gemmeiza 5, 3: Gemmeiza 7, 4: Gemmeiza 9, 5: Gemmeiza 10, 6: Gemmeiza 11, 7: Sids 1, 8: Sids 12, 9: Sids 13, 10: Shandaweel 1, 11: Lr 34 these varieties were identified to carry $\operatorname{Lr} 34$. While the wheat varieties Sakha 69, Sakha 93, Misr 1, Misr 2, Giza 160, Giza 163, Giza 164, Giza 165, Giza 168, Gemmeiza 5, Gemmeiza 7, Gemmeiza 9, Gemmeiza 10, Gemmeiza 11, Sids 1, Sids 12 and Sids 13 showed csLV34a allele. This result indicated the absence of $\operatorname{Lr} 34$ in these varieties. At the same time, durum wheat varieties showed the cslV34a allele indicated the absence of $\operatorname{Lr} 34$ (Figures 2 and 3 ) in addition of large fragment which it was unrelated to the gene $L r 34$. However, the diploid Aegilops tauschii the progenitor of $\mathrm{D}$ genome in cultivated wheat was tested and the presence of $c s L V 34$ a allele was demonstrated.

\section{Discussion}

A set of Egyptian wheat varieties released from 1979 to 2014 and an older variety namely Giza 139 were tested for the leaf rust resistance and for the variation in the locus $\operatorname{Lr} 34$. Thus rust incidence as final rust severity (FRS\%) was recorded for each of the tested genotypes. However, the wheat varieties Sids 12, Sids 13, Misr 1, Misr 2, Shandweel 1 , Beni Sweif 4 and Beni Sweif 5 were very resistant during the two growing seasons 201/12 and 2012/13 at both locations i.e. Shibin ElKom and Itay El-Baroud. Therefore it was concluded that the resistance in these varieties mainly due to race-specific resistance gene (s) against leaf rust.

Slow rust resistance at adult plant stage to leaf rust in the tested wheat varieties can be accurately measured by using area under disease progress curve (AUDPC) parameter, which considered the most convenient and a good reliable estimator for indicating the amount of rust infection occurred during an epidemic. Furthermore, AUDPC in particular is the result of all factors that influence disease development such as differences in environment, varieties and population of the pathogen $[22,24]$ reported that disease development and AUDPC are the best estimators of partial resistance in wheat to leaf rust.

According to the obtained results and depending on the values of AUDPC, it could be stated that the wheat genotypes $\operatorname{Lr} 34$, Giza 165, Giza 168, Sakha 8, Sakha 94, Sakha 95, Gemmeiza 5, Gemmeiza 7, Gemmeiza 9, Gemmeiza 10, Gemmeiza 11 and Sohag 3 have high level of slow rusting resistance under field conditions through the two growing seasons at both locations. These genotypes showed the lowest AUDPC values (less than 300), therefore this group of genotypes characterized as slow rusting resistant group. On the other hand, the wheat varieties Giza 160, Giza 163, Giza 64, Sakha 69, Sakha 93, Sids 1 and Giza 139 have been severely rusted, showing the highest values

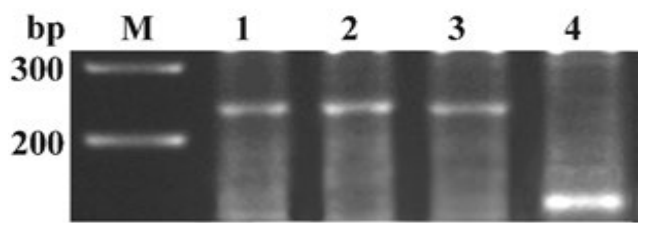

Figure 2: M: 100 bp ladder, 1: Sohag 3, 2: Beni Sweif 4, 3: Beni Sweif 5, 4: Lr 34 .

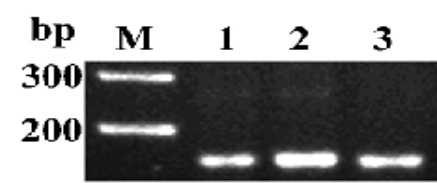

Figure 3: M: 100 bp ladder, 1: Sakha 8, 2: Aegilops tauschii, 3: Lr 34. 
of AUDPC (up to 840). Consequently, these varieties classified as the highly susceptible or fast rusting varieties group [25] found that the wheat cultivar Agra Local showed the highest value of AUDPC (1300), the wheat cultivar Kundan showed least AUDPC value (217). While the wheat cultivars Trap (317), Galvez-78 (344), Mango (412), Chris (504) and PBW-348 (737) [26] reported that the wheat cultivars Chenab 70, WL 711, Pak. 81 were fast rusting cultivars, while the cultivars Pavon, FSD and INQ-91 were slow rusting cultivars [27] found that the wheat varieties Giza 168 and Gemmeiza 7 showed partial resistance which they showed lowest values of FRS (\%) (did not exceed 250) and AUDPC (not more than 250). Marker-assisted selection offers the opportunity to select desirable lines on the basis of genotype rather than phenotype [28], especially in the case of combining different genes in a single genotype. Results of this study showed the usefulness of the SSR markers for identification of the leaf rust resistance gene $\operatorname{Lr} 34$ in the tested wheat genotypes.

However, the evaluation of the tested genotypes for two seasons at two locations gave an evidence of the present of slow rusting resistance gene (s). Therefore, using marker-assisted selection to confirm the presence of the resistance gene $L r 34$ was significant. The wheat varieties Giza 165, Giza 168, Gemmeiza 5, Gemmeiza 7, Gemmeiza 9, Gemmeiza 10 and Gemmeiza 11 did not show the 150 bp band but the AUDPC of these varieties showed that these varieties have slow rusting resistance gene (s). The resistance in these varieties appeared to be based on gene (s) other than $\operatorname{Lr} 34$. This gene (s) may be the slow rusting resistance $\operatorname{Lr} 46$ and/or $\operatorname{Lr} 68$. [27] found that, partial resistance in the two wheat varieties Gemmeiza 9 and Giza 168 mainly due to the presence of the adult plant resistance gene $\operatorname{Lr} 46$ which confirmed by genetic analysis. Moreover, [29] found that adult plant resistance to leaf rust (Puccinia triticina) in line Parula is governed by at least three independent slow rusting resistance genes i.e. $\operatorname{Lr} 34, \operatorname{Lr} 46$ and $\operatorname{Lr} 68$ gene on 7BL. [30] found that the partial resistance in the wheat cultivar HD2009 is similar in expression to that conferred by the gene $\operatorname{Lr} 34$, but cultivar HD2009 did not show leaf tip necrosis, a morphological marker tightly linked to the leaf rust resistance gene $\operatorname{Lr} 34$ [31]. However, varieties Sakha 8, Sakha 94, Sakha 95, Sids 13 and Shandweel 1 showed to carry the gene $\operatorname{Lr} 34$. Varieties Sakha 8, Sakha 94 and Sakha 95 showed slow rusting infection in AUDPC analysis. Thus the marker assist selection confirmed the presence of the important gene $\mathrm{Lr} 34$. It can be concluded that the slow rusting phenotype may be due the $L r 34$ gene. Slow rusting resistance for broad spectrum of pathotype due to $\operatorname{Lr} 34$ alone had been reviewed [32]. On the other hand, the two varieties Sids 13 and Shandweel 1 showed to carry the gene $\operatorname{Lr} 34$. However they showed race specific resistance. The resistance in these two varieties may be due to resistance genes other than $\operatorname{Lr} 34$ of slow rusting phenotype. Many leaf rust resistance genes showed race specific resistance in seedling stage and remained effective in the adult stage such as $\operatorname{Lr} 1, \operatorname{Lr} 10$ and $\operatorname{Lr} 21$ [33]. Since, these two varieties were recently released; therefore, they may contain one of these genes of this nature. Moreover, resistance to leaf rust in these varieties mainly due to race-specific resistance gene (s) [34] found that individual major genes for adult plant resistance to leaf rust can enhanced the effectiveness of resistance when combined in wheat cultivars. Therefore, presence of adult plant resistance gene (s) in the two varieties Sids 13 and Shandweel 1 may be masked the effect of the gene $\operatorname{Lr} 34$.

The obtained molecular results by the cslV34 marker in combination with the knowledge of the origin of the varieties understudy, may be enabled the most likely the origin of the important gene $\operatorname{Lr} 34$ in wheat Egyptian genotypes. Results of this research proved that Sakha 8 carried this gene. Also, previous results in our laboratory by [35] came with the same conclusion using genetic analysis. Sakha 8 was released in 1987. In this era 1970s, Akakomughi of Japanese origin appeared in the pedigree of all Egyptian cultivars released [36]. Akakomughi is a grandparent of spring wheat variety Frontana which was used widely as a source of $\operatorname{Lr} 34$ [6]. Therefore, it may be concluded that the $L r 34$ gene was first introduced to Egyptian varieties back in 1970s. Also, Sakha 8 may become the donor of this gene in subsequent derivatives of crosses which led to many recent varieties such as Sakha 94, Sakha 95, Sids 13 and Shandweel 1.

Finally, T. aestivum is hexaploid with a genome constitution of AABBDD, and was formed about 8,000 years ago from hybridization between T. turgidum (AABB) and A. tauschii (DD) [37]. Also, cslV34 marker is very specific for T. aestivum and $\mathrm{D}$ genome progenitor A. tauschii [11]. Therefore, it was investigated in A. tauschii diploid genome. The results of this research confirmed the presence of $c s l V 34 \mathrm{~b}$ allele and consequently the presence of the $\operatorname{Lr} 34$ gene for resistance in diploid D genome progenitor. The presence of $\operatorname{Lr} 34$ for resistance in the current $A$. tauschii suggests that this resistance gene may have arisen before hexaploid synthesis.

\section{References}

1. FAO GIEWS (2012) Global information and early warning system on food and agriculture. Country Briefs, Egypt.

2. Kolmer JA (2005) Tracking wheat rust on a continental scale. Curr Opin Plant Biol 8: 441-449.

3. Nazim M, El-Shehidi AA, Abdou YA, El-Daoudi YH (1983) Yield loss caused by leaf rust on four wheat cultivars under epiphytotic levels. 17-27.

4. McIntosh RA, Yamazaki Y, Dubcovsky J, Rogers J, Morris C, et al. (2012) Catalogue of Gene Symbols for Wheat. 58: 259-279.

5. Fahmi Al, Nazim M, Kahlifa SZ, El-Orabey WM (2003) Identification of seedling leaf rust resistance genes in Egyptian wheat. Egyptian Journal of Genetics Cytology 32: 357-373.

6. Kolmer JA, Singh RP, Garvin DF, Viccars L, William HM, et al. (2008) Analysis of the Lr 34/Yr18 rust resistance region in wheat germplasm. Crop Science 48 1841-1852.

7. Fahmi Al, Nazim M, Khalifa SZ, El-Orabey WM (2005) Genetics of adult plan resistance to leaf rust in Egyptian wheat. Egyptian Journal of Phytopathology 33: 1-10.

8. 8.Wilcoxson RD (1981) Genetics of slow rusting in cereals. Phytopathology 71: $989-993$

9. Krattinger SG, Lagudah ES, Spielmeyer W, Singh RP, Huerta-Espino J, et al (2009) A putative ABC transporter confers durable resistance to multiple fungal pathogens in wheat. Science 323: 1360-1363.

10. Singh RP (1993) Genetic association of gene Bdv1 for tolerance to barley yellow dwarf virus with genes $\operatorname{Lr} 34$ and $\mathrm{Yr} 18$ for adult plant resistance to rusts in bread wheat. Plant Disease 77: 1103-1106.

11. Lagudah ES, McFadden $\mathrm{H}$, Singh RP, Huerta-Espino J, Bariana $\mathrm{HS}$, et al. (2006) Molecular genetic characterization of the $\operatorname{Lr} 34 / \mathrm{Yr} 18$ slow rusting resistance gene region in wheat. Theoretical Applied Genetics 114:21-30.

12. Vanzetti LS, Campos $P$, Demichelis M, Lombardo LA, Aurelia PR, et al. (2011) Identification of leaf rust resistance genes in selected Argentinean bread wheat cultivars by gene postulation and molecular markers. Electronic Journal of Biotechnology 14: 1-17

13. Imbaby IA, Mahmoud MA, Hassan ME, Abd-El-Aziz AR (2014) Identification of leaf rust resistance genes in selected egyptian wheat cultivars by molecular markers. ScientificWorldJournal 2014: 574285

14. Fahmi Al, Nagaty HH, Eissa RA, Sherif MI, Abdel- Hameed MI (2004) Comparison of genetic relationships based on morphological, RAPD and microsatellite markers in hexaploid wheat. Alexandria Journal of Agriculture Research 49: 45-60.

15. Fahmi AI, El-Badawy MEM (2005) Genetic diversity in Egyptian wheat varieties based on AFLP markers. Alexandria Journal of Agriculture Research 50: 121-133. 
Citation: Fahmi Al, El-Shehawi AM, El-Orabey WM (2015) Leaf Rust Resistance and Molecular Identification of Lr 34 Gene in Egyptian Wheat. J Microb Biochem Technol 7: 338-343. doi:10.4172/1948-5948.1000236

16. Fahmi Al (2005) Microsatellites as markers for Egyptian wheat genotyping. Alexandria Journal of Agriculture Research 50: 127-136.

17. Fahmi Al, Nawar AA, Shehab El-Din TM, Ragab KE (2005) Inheritance and molecular characterization of leaf rust resistance in Egyptian wheat. Menoufia Journal of Agriculture Research 30: 1415-1441.

18. Tervet I, Cassell RC (1951) The use of cyclone separation in race identification of cereal rusts. Phytopathology 41: 282-285.

19. Large EC (1954) Growth stages in cereals Illustration of the feekes scale. Plant Pathology 3: 128-129.

20. Peterson RF, Campbell AB, Hannah AE (1948) A diagrammatic scale for estimating rust intensity on leaves and stems of cereals. The Canadian Journal of Research 60: 496-500.

21. Das MK, Rajaram S, Kronstad WE, Mundt CC, Singh RP (1993) Associations and genetics of three components of slow rusting in leaf rust of wheat. Euphytica 68: 99-109.

22. Pandey HN, Menon TCM, Rao MV (1989) A simple formula for calculating area under disease progress curve. Rachis 8: 38-39.

23. Saghai-Maroof MA, Loliman KM, Jorgens RA, Alard RW (1984) Ribosomal DNA spacer length polymorphisms in barley: Mendelian inheritance, chromosomal location, and population dynamics. Proceedings of the National Academy of Sciences of the United States of America 81: 8014-8018.

24. Broers LHM (1989) Partial resistance to wheat leaf rust in 18 spring wheat cultivars. Euphytica 44: 247-258.

25. Lal Ahamed M, Singh SS, Sharma JB, Ram RB (2004) Evaluation of inheritance to leaf rust in wheat using area under disease progress curve. Hereditas 141: 323-327.

26. Khan MA, Trevathan LE, Robbins JT (1997) Quantitative relationship between leaf rust and wheat yield in Mississippi. Plant Disease 81: 769-772.
27. Shahin SI, EI-Orabey WM (2015) Relationship between partial resistance and inheritance of adult plant resistance gene $\operatorname{Lr} 46$ of leaf rust in six bread wheat varieties. International Journal of Science and Research 4: 1511-1517.

28. El-Shehawi AM, Fahmi AI, Nagaty MA, Samra BN (2014) Marker assisted selection for fungal disease resistance in Taif grapes. WULFENIA Journal 21: 390-403.

29. Herrera-Foessel SA, Singh RP, Huerta-Espino J, Rosewarne GM, Periyannan SK, et al. (2012) Lr68: a new gene conferring slow rusting resistance to leaf rust in wheat. Theor Appl Genet 124: 1475-1486.

30. Khanna R, Bansal UK, Saini RG (2005) Genetics of durable resistance to leaf rust and stripe rust of an Indian wheat cultivar HD2009. J Appl Genet 46: 259-263.

31. 31. Singh RP (1992) Association between gene Lr 34 for leaf rust resistance and leaf tip necrosis in wheat. Crop Science 32: 874-878.

32. 32. Kolmer JA (2013) Leaf Rust of Wheat: Pathogen Biology, Variation and Host Resistance. Forests 4: 70-84.

33. Bolton MD, Kolmer JA, Xu WW, Garvin DF (2008) Lr34-mediated leaf rus resistance in wheat: transcript profiling reveals a high energetic demand supported by transient recruitment of multiple metabolic pathways. Molecular Plant-Microbe Interactions 21: 1515-1527.

34. German SE, Kolmer JA (1992) Effect of gene Lr34 in the enhancement of resistance to leaf rust of wheat. Theor Appl Genet 84: 97-105.

35. El-Orabey WM (2008) Studies on the adult plant resistance in wheat against leaf rust. WMELS EL-ORABEY.

36. Basnet BR, Ali MB, Ibrahim AMH, Payne T, Mosaad MG (2011) Evaluation of genetic bases and diversity of Egyptian wheat cultivars released during the last 50 years using coefficient of parentage. Communications in Biometry and Crop Science 6: 31-47.

37. El-Shehawi AM, Fahmi Al, Sayed SM, Elseehy MM (2012) Genetic Fingerprinting of Wheat and Its Progenitors by Mitochondrial Gene orf256. Biomolecules 2: 228-239. 